\title{
Aberrant V(D)J cleavages in T cell receptor $B$ enhancer- and p53-deficient lymphoma cells
}

\author{
YUN HEE KANG ${ }^{1,2}$, CHAE-YEON SON ${ }^{1}$, CHUL-HO LEE $^{3}$ and CHUN JEIH RYU ${ }^{1}$ \\ ${ }^{1}$ Institute of Bioscience, Department of Bioscience and Biotechnology, Sejong University, Seoul; \\ ${ }^{2}$ Medical Genomics Research Center, ${ }^{3}$ Disease Model Research Center, KRIBB, Daejon, Republic of Korea
}

Received January 13, 2010; Accepted February 11, 2010

DOI: 10.3892/or_00000785

\begin{abstract}
Previously, we generated thymic lymphoma cell lines from $\mathrm{E} \beta^{\mathrm{R} / \mathrm{R}} \mathrm{p} 53^{-/-}(\mathrm{EP})$ double mutant mice where the $\mathrm{T}$ cell receptor (TCR) $\beta$ enhancer (Eß) was deleted, and the $\mathrm{p} 53$ gene was inactivated. Here, we characterized the EP cell lines to study the roles of the Eß and $\mathrm{p} 53$ on TCRß rearrangements during lymphomagenesis. Recombination activation genes (RAGs) were expressed, while the TCR $\beta$ chain was not expressed in the EP cell lines. Dß-Jß rearrangements were not detected at all, and DB1 and Dß2 cleavages were also not detected in the EP cell lines. However, Jß cleavages suppressed in E $\$$ mutant thymocytes were readily detected in the EP cell lines. The Jß cleavages appeared to be uncoupled, aberrant, RAG-dependent and Eß-independent and were not detected in a p53 or E 3 single mutant background, suggesting that the Jß cleavages are selected in the Eß and p53 double mutant background. Sequence analysis showed that the cleavage occurred in the cryptic recombination signal sequences (RSSs) present throughout $\mathrm{J} ß$ gene segments. The results implicate that the uncoupled and aberrant $\mathrm{V}(\mathrm{D}) \mathrm{J}$ cleavages may contribute to double-strand break-mediated genome instability during lymphomagenesis in EP mice.
\end{abstract}

\section{Introduction}

$\mathrm{V}(\mathrm{D}) \mathrm{J}$ recombination is the process of assembling $\mathrm{T}$ cell receptor and immunoglobulin genes from $\mathrm{V}, \mathrm{J}$ and sometimes $\mathrm{D}$ gene segments and is the source of the immune system's tremendous diversity of antigen receptors $(1,2)$. V(D)J recombination can be divided into two steps, a cleavage step and a joining step. The initial cleavage step of V(D)J recombination is catalyzed by lymphocyte-specific proteins, recombination activating gene- 1 and -2 (RAG-1 and RAG-2,

Correspondence to: Dr Chun Jeih Ryu, Institute of Bioscience, Department of Bioscience and Biotechnology, Sejong University, 98 Gunja-Dong, Gwangjin-Gu, Seoul 143-747, Republic of Korea E-mail: cjryu@sejong.ac.kr

Key words: TCR $\beta$ gene enhancer, Eß-independent V(D)J cleavages, aberrant cleavages, lymphoma cells, cryptic recombination signal sequences respectively) which cleave DNA at the junctions between coding sequence and recombination signal sequences (RSSs) to produce double-strand breaks (DSBs) with hairpin coding ends and blunt signal ends $(2,3)$. A subsequent joining step through the non-homologous end joining pathway generates precise signal joints and imprecise coding joints. RSSs are composed of a conserved heptamer (consensus 5'-CACAG TG-3') and nanomer (consensus 5'-ACAAAAACC-3') separated by either 12 or 23 base pairs (bp) of varied sequences. Normally, DNA cleavage occurs in a coupled fashion that requires the pairing of 12-bp RSS and 23-bp RSS, although some studies have found that uncoupled cleavages are also possible (4-6). V(D)J recombination occurs in a tightly regulated fashion during lymphocyte development, exhibiting developmental stage, lineage and allele specificity. For example, the complete $\mathrm{VB}$-to-DßJß rearrangement is able to occur in $\mathrm{T}$ lymphocytes but not in B lymphocytes where the TCRß locus is also exposed to the same RAG. Thus, although recombination at different TCR and immunoglobulin (Ig) loci is mediated by the same RAG and conserved RSSs, complete rearrangements of TCR genes are limited to T cells, whereas complete rearrangements of $\mathrm{Ig}$ genes are limited to B cells. To explain how TCR genes and Ig genes are differentially targeted for recombination by the same enzyme and substrate, Alt et al proposed a hypothesis that V(D)J recombination is regulated by modulations in chromatin, which either augment or inhibit accessibility of gene segment to RAGs (7-9). Subsequent studies have shown that V(D)J recombination is regulated by transcriptional cis elements such as promoters and enhancers distributed throughout antigen receptor loci, which coordinate changes in the accessibility at gene segments (10-16).

At the TCRß locus, a single TCRß enhancer (Eß) has been described that is located between the $C B 2$ and VB14 gene (17). Knockout mouse studies have demonstrated that the Eß plays an important role in $\mathrm{V}(\mathrm{D}) \mathrm{J}$ recombination of linked TCRß gene segments $(11,12,15,16)$. In the absence of the $\mathrm{E} \beta$, there was a severe defect in the formation of Dß-to-Jß rearrangements, and the entire DB-Jß region became hypoacetylated, hypermethylated, and inaccessible to nuclease cleavage (18). The defect was more severe in the Vß-to-DßJß rearrangement. Thus, no TCR $\beta$ was produced and no $\alpha \beta$ $\mathrm{T}$ lymphocytes developed in the Eß-deficient mice $(11,12,19)$. It was also reported that the levels of $\mathrm{D} \beta-\mathrm{J} ß$ rearrangements were much more severely reduced than the levels of Dß and 
$\mathrm{J} ß$ signal ends in the Eß-deficient mice. Based on these observations, the E 3 was proposed to play a significant role in the joining steps of recombination (15). A detailed study on $\mathrm{D} \beta$ and $\mathrm{J} \beta$ cleavages and rearrangements further showed that $E ß$ regulates TCR $\beta$ rearrangement by promoting accessibility of $\mathrm{D} \beta$ and $\mathrm{J} \beta$ gene segments in CD4-CD8- double negative (DN) thymocytes and proper pairing between $\mathrm{D} \beta$ and $\mathrm{J} \beta$ gene segments for joining in $\mathrm{CD} 4{ }^{+} \mathrm{CD}^{+}$double positive (DP) thymocytes (16). Other studies found Eß-independent chromosomal accessibility of Dß1, Dß2 and Jß1 gene segments in DP thymocytes $(16,20)$, suggesting that the accessibility of $\mathrm{D} \beta$ and $\mathrm{J} \beta$ loci can be regulated in an $\mathrm{E} \beta$-independent manner depending on developmental stages.

In a previous study, we found that $E \beta^{R / R}$ thymocytes resulted in the blocking of $\mathrm{T}$ cell development at stages where RAG was expressed, and we found that the thymocytes were apoptotic (21). Introduction of a p53 deletion into $E \beta^{R / R}$ mice significantly decreased the apoptosis in double mutant thymocytes and accelerated the onset of lethal thymic lymphomas that harbor RAG-dependent chromosome 9, 12, and 14 aberrations (21). However, unexpectedly, TCRßassociated chromosomal aberrations were not observed in the double mutant mice. In this study, we therefore established cell lines from Eß- and p53-deficient thymic lymphomas and examined cleavages and rearrangements of Dß and Jß gene segments in these EP cell lines. We found that aberrant $J B$ cleavages occurred in the EP cell lines and found that the cleavages were uncoupled, RAG-dependent and Eßindependent.

\section{Materials and methods}

Mice and genotyping. The generation of $E \beta^{\mathrm{R} / \mathrm{R}}$ mice was previously described (16). p53 $3^{-/-}$mice were kindly provided by T. Jacks (Center for Cancer Research, Massachusetts Institute of Technology, Cambridge, MA). E ${ }^{R / R} \mathrm{p} 53^{-/-}$(EP) mice were generated by mating $E \beta^{R / R}$ with $\mathrm{p} 53^{-/-}$followed by the mating of F1 heterozygous siblings. Genotyping of $E \beta^{R / R}$ and $\mathrm{p} 53^{--}$were performed by PCR of genomic tail DNA as previously described $(16,22)$. All animal studies were performed according to the institutional guidelines.

Cell lines and flow cytometry. Parts of thymic lymphomas originating from $\mathrm{p} 53^{--}$or EP mice were minced with forceps in a tissue culture dish. The cells were transferred to a T75 flask in DMEM (Invitrogen, Carlsbad, CA), supplemented with $10 \%$ heat-inactivated fetal bovine serum, $0.1 \mathrm{mM}$ 2-mercaptoethanol, antibiotics-antimycotics (Invitrogen) and $2 \mathrm{mM}$ L-glutamine (Invitrogen) and incubated at $37^{\circ} \mathrm{C}$ in a $5 \% \mathrm{CO}_{2}$ atmosphere. The cells were then diluted 10-fold in the same flask and subsequently subcultured every 2-4 days at a 10 - or 20 -fold dilution into a new T75 flask. The cell lines were maintained continuously for several months and could be repeatedly frozen and thawed. Two RAG mutant lymphoma cell lines P4980 and P5424 were also maintained as described above (23). For the flow cytometric analysis, cells were incubated with anti-CD4,-CD8 and -TCRß which are direct conjugates from BD Pharmingen (San Diego, CA). Flow cytometry was performed on a FACScalibur apparatus (BD Immunocytochemistry Systems, San Jose, CA).
Southern and Northern blotting and PCR. Genomic DNA isolation and Southern blotting were performed as previously described (16). Dß1-Jß1, Dß2-Jß2 and Cß1 probes were as previously described (10). All probes were labeled by random priming with ${ }^{32} \mathrm{P}-\mathrm{dCTP}$. The semi-quantitative nested PCR assays for JAK3, Dß1-Jß1, Dß1-Jß2 and Dß2-Jß2 rearrangements, and the ligation-mediated (LM)-PCR assays for 3'Dß1, 3'Dß2, 5'Jß1, 5'Jß2 and 5'Dß1 cleavages were performed as previously described (16). The LM-PCR assays for 5'Dß2 and 5'JH4 cleavages were also performed as described above. Primer sequences and oligonucleotide probes were as follows: 5'Dß2C, 5'-GTGATATAGATGTTCTCCCAGAG TG-3'; 5'Dß2D, 5'-GACCACATTCAGAACAGGGCTCC-3'; 5'Dß2 probe, 5'-TGCCACCTGGTCTCCCTGCCCCTGC-3'; 5'JH4A, 5'-CAGGGTCAGTGACTGTCAGGTTTC-3'; 5'JH4B, 5'-GAGGTGAGGCTGGAATATAGGTCA-3'; 5'JH4 probe, 5'-GATTCTTGTGTGACACCAAGA-3'. PCR products were cloned into pCR2.1-TOPO (Invitrogen) for sequencing. For Northern blot analysis, $10 \mu \mathrm{g}$ of total RNA was fractionated on a $1 \%$ formaldehyde agarose gel and transferred to a Zeta-probe membrane (Bio-Rad). The RAG1 and RAG2 cDNA probes used in the Northern blotting were isolated from pTet-R1 and pTet-R2 (24). The GAPDH cDNA probe was described elsewhere (21).

\section{Results}

Establishment of EP lymphoma cell lines. Previously, we found that introduction of the $\mathrm{E} B$ mutation into $\mathrm{p} 53^{-/-}$mice dramatically accelerated the onset of lethal thymic lymphomas that harbor RAG-dependent chromosome 9, 12 and 14 aberrations, and all double mutant mice developed terminal thymic lymphomas by 11-17 weeks of age (21). To study TCRß locus rearrangements in the lymphomas, we established thymic lymphoma cell lines from $\mathrm{p} 53^{-/-}$and EP mice. Two lymphoma cell lines P99 and P101 were established from p53 ${ }^{-/-}$mice through serial passages in cell culture, which were DP cells that express TCRß (Fig. 1A). Four lymphoma cell lines EP54, EP70, EP116 and EP173 were also established from EP mice through serial passages in cell culture. Most of the EP54, EP70 and EP173 cells were CD8 ${ }^{+}$SP cells, while the EP116 cells were composed of DN (71\%) and CD8 ${ }^{+} \mathrm{SP}$ cells $(26 \%)$ (Fig. 1A). TCRß signaling has been known to provoke down-regulation of RAG1 and RAG2 expression (25). Consistent with this notion, RAG transcripts were significantly down-regulated in the $\mathrm{p} 53^{-/}$lymphoma cell lines (Fig. 1B). In contrast to the lymphoma cell lines originating from the $\mathrm{p} 53^{-/-}$mice, all of the lymphoma cell lines from the EP mice did not express TCRß at all (Fig. 1A, bottom row), and both the RAG1 and RAG2 transcripts were detected in all of the EP cell lines as expected (Fig. 1B).

$D \beta-J \beta$ rearrangements in EP cell lines. Previously, we examined RAG activity by assaying for the presence of rearrangements at antigen receptor loci in EP thymic lymphoma cells by Southern blotting (21). We detected IgH and TCR $\alpha$ gene rearrangements, but did not detect TCR $\beta$ gene rearrangements. As RAG expression was continuously observed in the four EP cell lines (Fig. 1B), we sought to detect Dß1-Jß1, Dß1-Jß2 and Dß2-Jß2 rearrangements in the 
A.

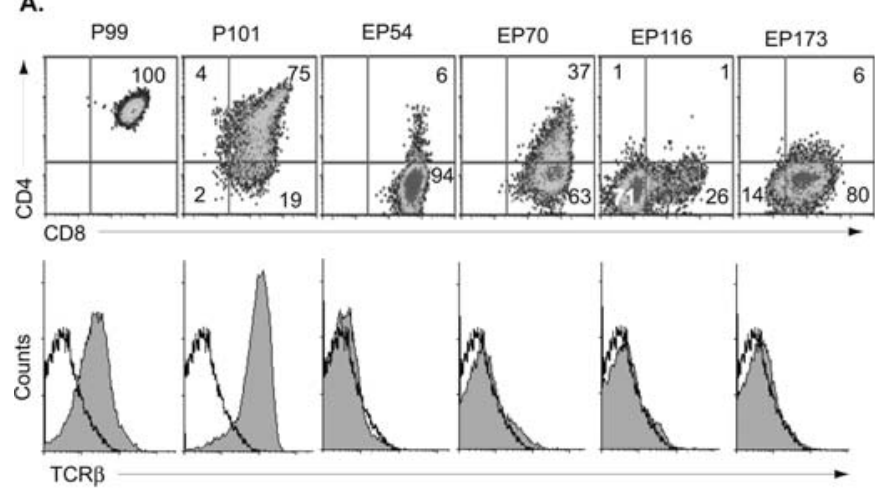

B.

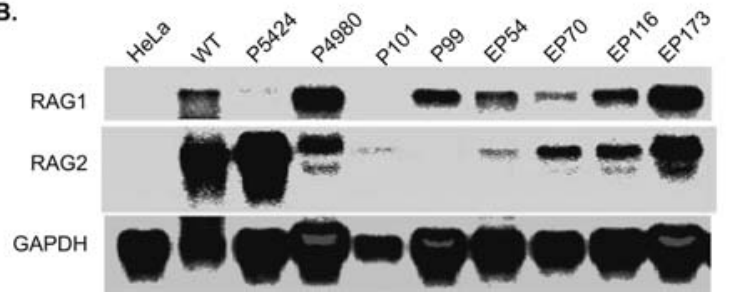

Figure 1. Establishment of thymic lymphoma cells from $\mathrm{p} 53^{-/-}$and $\mathrm{E} 3^{\mathrm{R} / \mathrm{R}} \mathrm{p} 53^{-/}$ mice. (A) Two lymphoma cell lines P99 and P101 were established from p53/- thymic lymphoma tissues, and four lymphoma cell lines EP54, EP70, EP116 and EP173 were established from Eß $3^{\mathrm{R} / \mathrm{R}} \mathrm{p} 53^{-/-}$thymic lymphoma tissues. CD4 and CD8 (upper row), and TCRß staining profiles (lower row) are shown for live cells. Numbers indicate the average percentages of cells in the gated areas. The unfilled population represents TCRß staining in the RAG2-deficient lymphoma cell line P4980, whereas the filled population represents TCRß staining in the indicated lymphoma cell lines. (B) Northern blot analysis of RAG transcripts in total RNAs from the indicated cells. Total RNAs from wild-type thymocytes, P5424 and P4980 cells were included as controls. Hybridization with a GAPDH probe was used to normalize the relative amount of RNA loading in the different lanes.

four EP cell lines by PCR amplification. TCRß gene rearrangements were not detected in the four EP cell lines (Fig. 2). However, Dß1-Jß2 and Dß2-Jß2 rearrangements were readily detected in 4-week-old lymphoma-free EP mice, although the levels of the rearrangement products were reduced approximately between 25 - and 125-fold (16). The results suggest that EP thymocytes whose Dß-Jß regions undergo rearrangements are removed from the pool, and EP thymocytes whose $\mathrm{D} \beta-\mathrm{J} \beta$ regions remain in the germline configuration are selected during the progression of lymphomagenesis. In contrast, as expected from TCRß expression, clonal TCRß gene rearrangements were detected in the $\mathrm{p} 53^{-1-}$ lymphoma cell lines (data not shown).

$J \beta$ cleavages in EP lymphoma cell lines. TCRß rearrangement can be divided into two steps, a cleavage step and a joining step. Although we did not detect any $\mathrm{D} \beta-\mathrm{J} ß$ rearrangements in the EP cell lines, it does not mean that the Dß-Jß regions are not accessible to RAG proteins. Previous studies have shown that the Eß regulates TCR $\beta$ rearrangements in both steps depending on the developmental stage $(15,16)$. In DP thymocytes, Dß1 and D 32 cleavages were maintained even in the absence of the Eß (16). To study whether the Dß and J 3 cleavages are affected in EP cell lines, genomic DNAs were isolated from the lymphoma cell lines and wild-type and
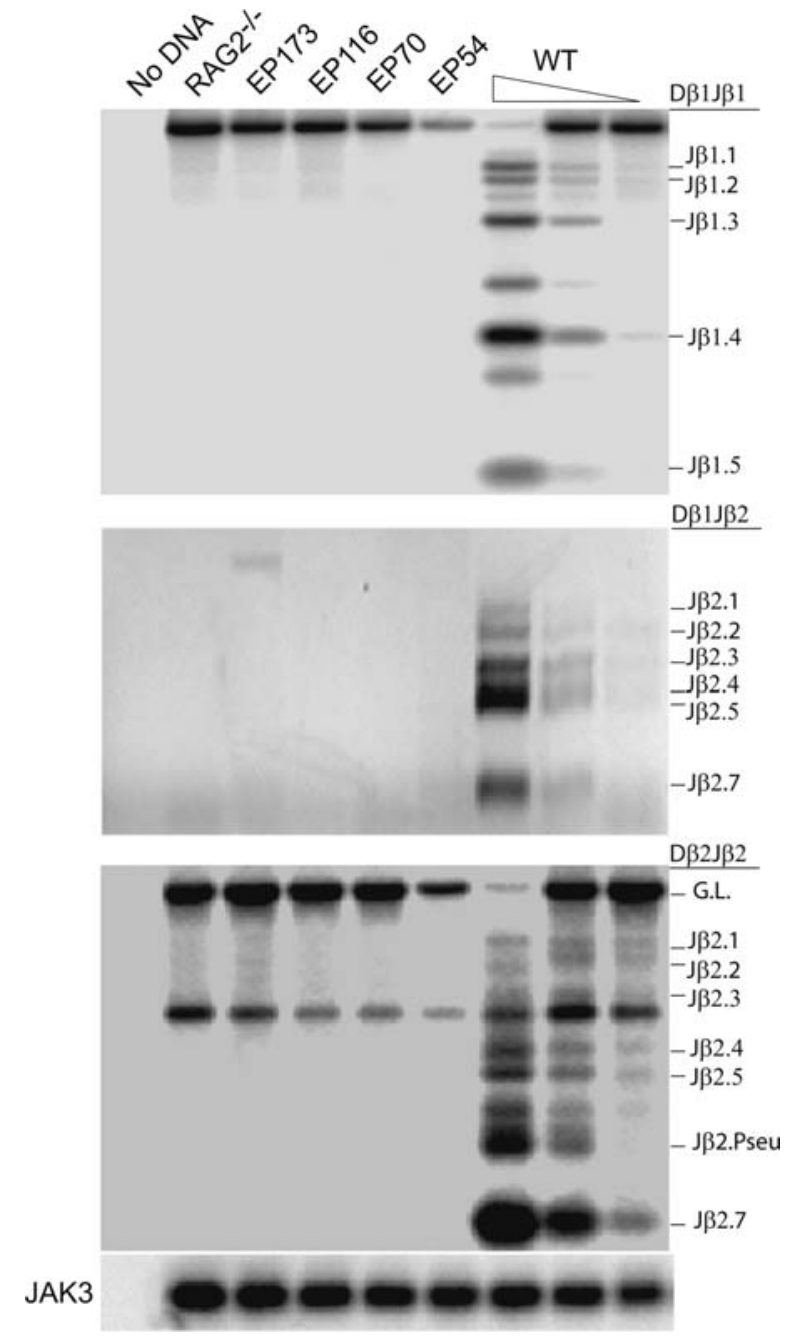

Figure 2. PCR assay for Dß1-Jß1, DB1-Jß2 and Dß2-Jß2 rearrangements in the EP cell lines. Genomic DNAs were isolated from wild-type thymocytes and EP54, EP70, EP116, and EP173 cell lines. Wild-type DNA was either undiluted or diluted 5-fold with $\mathrm{RAG}^{-/-}$kidney DNA. Various rearrangements were measured by a semi-quantitative PCR. JAK3 was amplified to verify DNA quality and relative amount. PCR products were separated on agarose gels and hybridized with specific DB probes. Rearrangements to different $\mathrm{J} ß$ are labeled. G.L, germline. Representative data from four different experiments are shown.

$E \beta^{R / R}$ thymocytes. DNA cleavages from RAG-mediated V(D)J cleavages were then measured by a semi-quantitative nested LM-PCR (Fig. 3). In wild-type thymocytes, 3'Dß1, 3'Dß2, 5'Jß1, 5'Jß2, 5'Dß1 and 5'Dß2 cleavages were readily detected (Fig. 3, right). In Eß ${ }^{R / R}$ thymocytes, 5'Jß1 cleavage was not detected at all, and the levels of 3'Dß1, 3'Dß2 and 5'Jß2 cleavages were also substantially reduced as expected from a previous finding (16). 5'JH4 cleavage was also readily detected in $E \beta^{R / R}$ and wild-type thymocytes, consistent with previous findings (26,27). However, 3'Dß1, 3'Dß2 and 5'JH4 cleavages detected in the $E \beta^{R / R}$ thymocytes were not detected in the EP cell lines (Fig. 3, middle), suggesting that the cells containing the cleavages may be selected against during the progression of lymphomagenesis in EP mice. In contrast to these cleavages, 5'Jß1 and 5'JB2 cleavage products suppressed in the E $\beta^{\mathrm{R} / \mathrm{R}}$ thymocytes were readily detected in the EP cell lines (Fig. 3, middle). The Jß cleavages were not detected in P5424 and 
Table I. Comparison of Jß1, Jß2, Dß1 and Dß2 cleavage sites in wild-type and $E \beta^{R / R}$ thymocytes and various $E \beta^{R / R} p 53^{-1-}$ lymphoma cell lines.

\begin{tabular}{|c|c|c|c|c|}
\hline & $\mathrm{J} ß 1$ & $\mathrm{~J} ß 2$ & $D ß 1$ & $\mathrm{D} \beta 2$ \\
\hline WT & $\begin{array}{l}\text { Jß1.1 CACAGTG (hep) 9X } \\
\text { Jß1.2 CACACTA (hep) 1X }\end{array}$ & $\begin{array}{l}\text { Jß2.1 CACAGCA (hep) 5X } \\
\text { Jß2.3 CACAGCC (hep) 1X }\end{array}$ & $\begin{array}{l}\text { CACGGTG (hep) } 4 X \\
\text { CGGTGAT (+2) } 1 X\end{array}$ & CACAATG (hep) $3 X$ \\
\hline$E \beta^{R / R}$ & & & CACGGTG (hep) 7X & CACAATG (hep) $4 \mathrm{X}$ \\
\hline EP54 & $\begin{array}{l}\text { Jß1.1CACGGAG }(+106) 1 \mathrm{X} \\
\text { Jß1.2 CACCATA }(+228) 3 \mathrm{X} \\
\mathrm{J} \beta 1.2 \text { CACCTTT }(+74) 1 \mathrm{X}\end{array}$ & $\begin{array}{l}\text { Jß2.3 CACAGCC (hep) } 1 \mathrm{X} \\
\text { Jß2.1 CACATTC (-71) } 1 \mathrm{X}\end{array}$ & & \\
\hline EP70 & $\begin{array}{l}\text { Jß1.2 CACCCGA }(+250) 1 X \\
\text { Jß1.2 CGAGGTT }(+246) 1 X \\
\text { Jß1.2 CACCATA }(+228) 1 X \\
\text { Jß1.2 CACACCC }(+74) 2 X\end{array}$ & $\begin{array}{l}\text { Jß2.3 CACAGCC (hep) 2X } \\
\text { Jß2.1 CACATTC (-71) 2X }\end{array}$ & & \\
\hline EP116 & $\begin{array}{l}\text { Jß1.1 CACGGAG }(+106) 1 \mathrm{X} \\
\text { Jß1.2 ACTCCAC }(+232) 1 \mathrm{X} \\
\mathrm{J} ß 1.2 \text { CACCATA }(+228) 2 \mathrm{X} \\
\mathrm{J} ß 1.2 \text { CACCTTT }(+196) 1 \mathrm{X} \\
\mathrm{J} ß 1.2 \text { CACACCC }(+74) 3 \mathrm{X} \\
\mathrm{J} ß 1.3 \text { ACAGACA }(+115) 1 \mathrm{X}\end{array}$ & Jß2.3 CACAGCC (hep) $1 \mathrm{X}$ & & \\
\hline EP173 & $\begin{array}{l}\text { Jß1.1 CACGGAG }(+106) 1 \mathrm{X} \\
\text { Jß1.2 CACCTTT }(+196) 1 \mathrm{X} \\
\text { Jß1.2 CACACCC }(+74) 2 \mathrm{X} \\
\text { Jß1.2 CACCCAA }(+72) 1 \mathrm{X} \\
\text { Jß1.3 CACTGCA }(+369) 1 \mathrm{X}\end{array}$ & $\begin{array}{l}\text { Jß2.1 CACAGCA (hep) } 1 \mathrm{X} \\
\text { Jß2.1 AGAATTC (-22) 3X }\end{array}$ & & \\
\hline
\end{tabular}

The first $\mathrm{C}$ of the consensus heptamer of 12-RSS is counted as nucleotide -1. Hep, heptamer; WT, wild-type.

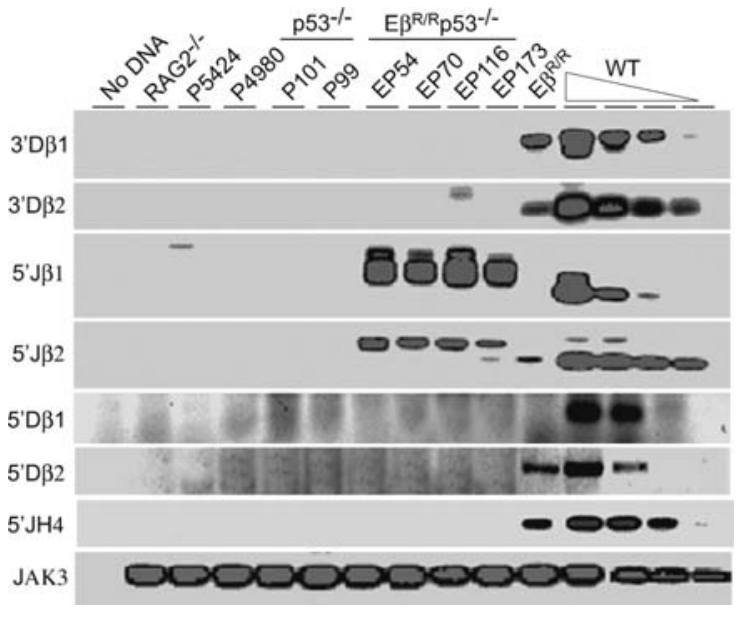

Figure 3. LM-PCR assays for Dß, Jß and JH4 cleavages. DNAs from the indicated cells were used to assay for DNA cleavages derived from RAGmediated cleavages at 3'Dß1, 3'Dß2, 5'Jß1, 5'Jß2, 5'Dß1, 5'Dß2 and 5'JH4 by LM-PCR. Wild-type thymocyte DNA was either undiluted or serially diluted every 3 -fold, and was included as a control. JAK3 was amplified to verify DNA quality and relative amount. PCR products were separated on agarose gels and hybridized with specific Dß1, Dß2, Jß1, Jß2 and JH4 probes. Representative data from four different experiments are shown.

P4980 (Fig. 3, left) where parts of the RAG genes were deleted, and were not detected in p53-deficient P99 and P101 where RAG transcripts were significantly down-regulated due to
TCRß expression (Fig. 1). The results suggest that the Jß cleavages were Eß-independent and RAG-dependent. Furthermore, the $\mathrm{J} \beta$ cleavages appeared to be uncoupled, as $3^{\prime} \mathrm{D} \beta 1$ and $3^{\prime} \mathrm{D} \beta 2$ cleavages were not detected. In the $E \beta^{\mathrm{R} / \mathrm{R}}$ thymocytes, 5'Dß2 cleavage and non-standard Dß1-Dß2-Jß2 rearrangements were detected (16). However, 5'Dß1 and 5'Dß2 cleavages and non-standard Dß1-Dß2-Jß2 rearrangements were not detected at all in the EP cell lines (Figs. 2 and 3), confirming again that the $\mathrm{J} ß$ cleavages were uncoupled. Taken together, the results suggest that Eß-independent and RAG-dependent J 3 cleavages are uncoupled and are selected in EP cell lines.

$J \beta$ cleavages occur at cryptic RSSs. The sizes of the J 3 cleavage products in the EP cell lines were different from those in the $E \beta^{R / R}$ and wild-type thymocytes (Fig. 3). To examine the nature of the cleavages, we sought to clone and sequence the cleavage products from Dß1, Dß2, Jß1, Jß2, and JH4 cleavages. Twenty-three out of $24(\sim 96 \%)$ cleavage products cloned from wild-type thymocytes started with the consensus heptamers, indicating that the cleavages occurred at the junction between RSSs and coding sequences (Table I). The $\mathrm{J} ß 1$ cleavage product was not cloned in the $E \beta^{\mathrm{R} / \mathrm{R}}$ thymocytes. Twenty-five J 31 cleavage products were cloned and sequenced in the EP cell lines (Table I), and all of the cleavage products $(100 \%)$ did not start with the consensus heptamers (the first $\mathrm{C}$ of the heptamer of 12-RSS is counted as nucleotide -1). 
They were cleaved downstream of the original Jß1 RSSs. The Jß1 cleavage sites were very heterogeneous as 10 different cleavage sites were found in the EP cell lines. Furthermore, 23 out of the $25(92 \%)$ cleavage sites found in the Jß1 gene segments started with 5'-CAC-3' (the first three residues of the consensus heptamer), which indicated that the cleavages occurred at the cryptic RSSs present throughout the Jß1 gene locus $(28,29)$. Although the JB2 cleavage product was not cloned in the $E \beta^{R / R}$ thymocytes, $11 \mathrm{~J} \beta 2$ cleavage products were cloned from the EP cell lines. Six cleavage products ( $55 \%)$ were cleaved at the consensus heptamers, and 5 cleavage products were cleaved upstream of the original Jß2.1 RSSs (Table I). The results suggest that the J 32 cleavages in the EP cell lines were also aberrant, although the percentage of aberrant JB2 cleavages was not comparable with that of the aberrant Jß1 cleavages. On the other hand, all Dß1 and Dß2 cleavage products $(100 \%)$ in the $E \beta^{R / R}$ thymocytes started with the consensus heptamers (Table I), indicating that the cleavages in the $E \beta^{R / R}$ thymocytes occurred at the junction between RSSs and coding sequences. The results indicated that the Eß-independent V(D)J cleavages in the EP cell lines were heterogeneous and aberrant, while those in the $\mathrm{E} \beta^{\mathrm{R} / \mathrm{R}}$ thymocytes were normal standard cleavages .

\section{Discussion}

Many studies have shown that the accessibility of antigen receptor loci to $\mathrm{V}(\mathrm{D}) \mathrm{J}$ recombinase is regulated by transcriptional cis elements such as promoters and enhancers distributed throughout antigen receptor loci (10-16). The Eß is a single enhancer throughout the TCRß locus and is known to be responsible for the accessibility of Dß-Jß gene segments. As expected, the control of J 31 and Jß2 accessibility was reported to be strictly dependent on the Eß (30). However, in this study, aberrant $\mathrm{J} ß 1$ and $\mathrm{J} ß 2$ cleavages were readily detected in the EP cell lines (Fig. 3 and Table I). As the $\mathrm{J} ß$ cleavages were not detected in the $\mathrm{p} 53^{-/}$lymphoma cell lines and wild-type thymocytes where the $\mathrm{E} \beta$ was normal, the aberrant $\mathrm{J} ß$ cleavages appear to be suppressed in the presence of the E $\beta$. Furthermore, the aberrant $\mathrm{J} \beta$ cleavages appeared to be selected in the absence of 553 since they were not detected in the $E \beta^{R / R}$ thymocytes where the $\mathrm{p} 53$ gene was normal. Therefore, it is likely that the E $\beta$-independent $\mathrm{J} \beta$ accessibility could occur in a certain developmental stage where p53 expression is inactivated. Some studies have also shown that Eß-independent $\mathrm{J} ß$ accessibility increases during DN to DP thymocyte differentiation $(20,31)$, and the DN to DP transition of thymocytes was suggested to be dependent on p53 inactivation (32). As p53 is known as a chromatin accessibility factor and p53-mediated chromosomal accessibility or inaccessibility is possible $(33,34)$, it is possible that $\mathrm{J} \beta$ loci become accessible to RAG-mediated cleavage in the absence of p53 during the progression of lymphomagenesis. We found two putative $\mathrm{p} 53$-binding sites in the $\mathrm{D} B-\mathrm{J} \beta$ region by using the TFSEARCH program (http://www.cbrc.jp/research/db/ TFSEARCH.html) and TRANSFEC databases (35). One is between $\mathrm{J} \beta 1.2$ and $\mathrm{J} ß 1.3$, and the other is between Dß2 and $\mathrm{J}$ 32.1. Whether p53 is able to bind two putative binding sites and is able to regulate the accessibility of the Dß-Jß region remains to be investigated. Furthermore, a recent study showed that deletion of a small genomic region containing five of the six Jß1 gene segments led to a marked decrease in transcription and rearrangements involving the Dß1 and Jß31.1 gene segments (36), which suggest that transcription and accessibility of Jß1 gene segments can be controlled by an additional cis-acting regulatory element. Therefore, it is also likely that $\mathrm{E} \beta$-independent $\mathrm{J} ß$ cleavages occur in a certain developmental stage where an additional cis-acting element controls accessibility of $\mathrm{J} ß$ gene segments in the context of p53 inactivation.

In a previous study, introduction of the p53 mutation into $E \beta^{R / R}$ mice rescued the thymocytes from apoptosis and allowed the thymocyte development to continue even in the absence of a successful TCRß rearrangement (21). As a consequence, the double mutant thymocytes developed into lethal thymic lymphomas with RAG-mediated chromosome 9, 12, and 14 aberrations (21). In the beginning, introduction of p53 deficiency was expected to allow the persistent presence of unprocessed DNA double-strand breaks (DSB) originating from the TCRß locus during cell proliferation, which would provoke TCRß-mediated chromosomal translocations. It was reported that $\mathrm{V}(\mathrm{D}) \mathrm{J}$-mediated translocations involving the TCRß and various oncogenes occurred between the Dß1 and cryptic RSSs of various oncogenes in many cases (37). In a large number of cases, a proto-oncogene is juxtaposed to a strong and active regulatory element from antigen receptor loci, and the ectopic/overexpression of the proto-oncogene generally constitutes the initial step of tumorigenesis (37). However, we were not able to detect any TCRß-associated translocations in the EP lymphomas (21), suggesting that translocations involving Eß-deleted TCRß loci and oncogenes are not selected during lymphomagenesis. In this study, instead, we found the continued $\mathrm{J} ß$ cleavages in the EP cell lines (Fig. 3). Most $E \beta^{R / R}$ thymocytes undergo massive apoptosis, and the apoptotic cells are partly rescued by p53 deletion (21). However, the EP thymocytes are still susceptible to apoptosis even in the context of a p53 deletion (21). The EP cell lines that we established through this study were also continuously susceptible to apoptosis during serial passages in cell culture (data not shown). Therefore, it is likely that the unprocessed $\mathrm{J} \beta$ cleavages were involved in the p53independent apoptotic pathway and contributed DSB-mediated genome instability in the EP cell lines. Although we do not have the direct evidence that aberrant $J ß$ cleavages are involved in accelerating lymphomagenesis in EP mice, they can still significantly impact genome instability, which may play an important role in T cell tumorigenesis (29,37-40). The correlation between lymphomagenesis and continued persistence of aberrant $\mathrm{V}(\mathrm{D}) \mathrm{J}$ cleavages remains to be investigated. In summary, we found, for the first time, Eßindependent $\mathrm{V}(\mathrm{D}) \mathrm{J}$ cleavages in $\mathrm{E} ß$ and p53 double mutant lymphoma cells. The Eß-independent V(D)J cleavages were uncoupled and aberrant and were selected in the p53deficient background.

\section{Acknowledgements}

This study was supported by the Korea Research Foundation Grant funded by the Korean Government (MOEHRD, Basic Research Promotion Fund) (KRF-2007-E00444). 


\section{References}

1. Tonegawa S: Somatic generation of antibody diversity. Nature 302: 575-581, 1983

2. Gellert M: V(D)J recombination: RAG proteins, repair factors, and regulation. Annu Rev Biochem 71: 101-132, 2002.

3. Bassing $\mathrm{CH}$, Swat $\mathrm{W}$ and Alt FW: The mechanism and regulation of chromosomal V(D)J recombination. Cell 109: S45-S55, 2002.

4. Ramsden DA, McBlane JF, van Gent DC and Gellert M: Distinct DNA sequence and structure requirements for the two steps of V(D)J recombination signal cleavage. EMBO J 15: 3197-3206, 1996.

5. Zhang $\mathrm{M}$ and Swanson PC: V(D)J recombinase binding and cleavage of cryptic recombination signal sequences identified from lymphoid malignancies. J Biol Chem 283: 6717-6727, 2008

6. Cuomo CA, Mundy CL and Oettinger MA: DNA sequence and structure requirements for cleavage of $\mathrm{V}(\mathrm{D}) \mathrm{J}$ recombination signal sequences. Mol Cell Biol 16: 5683-5690, 1996.

7. Sleckman BP, Gorman JR and Alt FW: Accessibility control of antigen-receptor variable-region gene assembly: role of cisacting elements. Annu Rev Immunol 14: 459-481, 1996.

8. Alt FW, Blackwell TK and Yancopoulos GD: Development of the primary antibody repertoire. Science 238: 1079-1087, 1987.

9. Stanhope-Baker P, Hudson KM, Shaffer AL, Constantinescu A and Schlissel MS: Cell type-specific chromatin structure determines the targeting of $\mathrm{V}(\mathrm{D}) \mathrm{J}$ recombinase activity in vitro. Cell 85: 887-897, 1996

10. Whitehurst CE, Chattopadhyay S and Chen J: Control of V(D)J recombinational accessibility of the $\mathrm{D}$ beta 1 gene segment at the TCR beta locus by a germline promoter. Immunity 10: 313-322, 1999

11. Bories JC, Demengeot J, Davidson L and Alt FW: Gene-targeted deletion and replacement mutations of the T-cell receptor betachain enhancer: the role of enhancer elements in controlling V(D)J recombination accessibility. Proc Natl Acad Sci USA 93. 7871-7876, 1996.

12. Bouvier G, Watrin F, Naspetti M, Verthuy C, Naquet P and Ferrier P: Deletion of the mouse T-cell receptor beta gene enhancer blocks alphabeta T-cell development. Proc Natl Acad Sci USA 93: 7877-7881, 1996.

13. Krangel MS: Gene segment selection in V(D)J recombination: accessibility and beyond. Nat Immunol 4: 624-630, 2003

14. Mostoslavsky R, Alt FW and Bassing CH: Chromatin dynamics and locus accessibility in the immune system. Nat Immunol 4: 603-606, 2003

15. Hempel WM, Stanhope-Baker P, Mathieu N, Huang F, Schlissel MS and Ferrier P: Enhancer control of V(D)J recombination at the TCRbeta locus: differential effects on DNA cleavage and joining. Genes Dev 12: 2305-2317, 1998.

16. Ryu CJ, Haines BB, Draganov DD, et al: The T cell receptor beta enhancer promotes access and pairing of Dbeta and Jbeta gene segments during V(D)J recombination. Proc Natl Acad Sci USA 100: 13465-13470, 2003.

17. Hood L, Rowen L and Koop BF: Human and mouse T-cell receptor loci: genomics, evolution, diversity, and serendipity. Ann NY Acad Sci 758: 390-412, 1995.

18. Mathieu N, Hempel WM, Spicuglia S, Verthuy C and Ferrier P: Chromatin remodeling by the $\mathrm{T}$ cell receptor (TCR)-beta gene enhancer during early $\mathrm{T}$ cell development: Implications for the control of TCR-beta locus recombination. J Exp Med 192: 625-636, 2000 .

19. Leduc I, Hempel WM, Mathieu N, et al: T cell development in TCR beta enhancer-deleted mice: implications for alpha beta T cell lineage commitment and differentiation. J Immunol 165: 1364-1373, 2000.

20. Mathieu N, Spicuglia S, Gorbatch S, et al: Assessing the role of the $T$ cell receptor beta gene enhancer in regulating coding joint formation during $\mathrm{V}(\mathrm{D}) \mathrm{J}$ recombination. J Biol Chem 278 : 18101-18109, 2003
21. Haines BB, Ryu CJ, Chang S, et al: Block of T cell development in P53-deficient mice accelerates development of lymphomas with characteristic RAG-dependent cytogenetic alterations. Cancer Cell 9: 109-120, 2006.

22. Jacks T, Remington L, Williams BO, et al: Tumor spectrum analysis in p53-mutant mice. Curr Biol 4: 1-7, 1994.

23. Doty RT, Xia D, Nguyen SP, Hathaway TR and Willerford DM: Promoter element for transcription of unrearranged T-cell receptor beta-chain gene in pro-T cells. Blood 93: 3017-3025, 1999.

24. Shockett P, Difilippantonio M, Hellman N and Schatz DG: A modified tetracycline-regulated system provides autoregulatory, inducible gene expression in cultured cells and transgenic mice. Proc Natl Acad Sci USA 92: 6522-6526, 1995.

25. Michie AM and Zuniga-Pflucker JC: Regulation of thymocyte differentiation: pre-TCR signals and beta-selection. Semin Immunol 14: 311-323, 2002.

26. Kurosawa Y, von Boehmer H, Haas W, Sakano H, Trauneker A and Tonegawa S: Identification of D segments of immunoglobulin heavy-chain genes and their rearrangement in T lymphocytes. Nature 290: 565-570, 1981

27. Born W, White J, Kappler J and Marrack P: Rearrangement of $\mathrm{IgH}$ genes in normal thymocyte development. J Immunol 140: 3228-3232, 1988

28. Lewis SM, Agard E, Suh S and Czyzyk L: Cryptic signals and the fidelity of V(D)J joining. Mol Cell Biol 17: 3125-3136, 1997.

29. Marculescu R, Le T, Simon P, Jaeger U and Nadel B: V(D)Jmediated translocations in lymphoid neoplasms: a functional assessment of genomic instability by cryptic sites. J Exp Med 195: 85-98, 2002.

30. Oestreich KJ, Cobb RM, Pierce S, Chen J, Ferrier P and Oltz EM: Regulation of TCRbeta gene assembly by a promoter/enhancer holocomplex. Immunity 24: 381-391, 2006.

31. Senoo M, Mochida N, Wang L, et al: Limited effect of chromatin remodeling on $\mathrm{D}$ (beta)-to-J(beta) recombination in $\mathrm{CD} 4^{+} \mathrm{CD}^{+}$thymocytes: implications for a new aspect in the regulation of TCR beta gene recombination. Int Immunol 13: 1405-1414, 2001

32. Haks MC, Krimpenfort P, van den Brakel JH and Kruisbeek AM: Pre-TCR signaling and inactivation of p53 induces crucial cell survival pathways in pre-T cells. Immunity 11: 91-101, 1999.

33. Rubbi CP and Milner J: p53 is a chromatin accessibility factor for nucleotide excision repair of DNA damage. EMBO J 22: 975-986, 2003.

34. Allison SJ and Milner J: Remodelling chromatin on a global scale: a novel protective function of p53. Carcinogenesis 25: 1551-1557, 2004

35. Heinemeyer T, Wingender E, Reuter I, et al: Databases on transcriptional regulation: TRANSFAC, TRRD and COMPEL. Nucleic Acids Res 26: 362-367, 1998.

36. Khor B, Mahowald GK, Khor K and Sleckman BP: Functional overlap in the cis-acting regulation of the $\mathrm{V}(\mathrm{D}) \mathrm{J}$ recombination at the TCRbeta locus. Mol Immunol 46: 321-326, 2009.

37. Marculescu R, Vanura K, Montpellier B, et al: Recombinase, chromosomal translocations and lymphoid neoplasia: targeting mistakes and repair failures. DNA Repair 5: 1246-1258, 2006.

38. Reddy YV, Perkins EJ and Ramsden DA: Genomic instability due to $\mathrm{V}(\mathrm{D}) \mathrm{J}$ recombination-associated transposition. Genes Dev 20: 1575-1582, 2006.

39. Vanura K, Montpellier B, Le T, et al: In vivo reinsertion of excised episomes by the $\mathrm{V}(\mathrm{D}) \mathrm{J}$ recombinase: a potential threat to genomic stability. PLoS Biol 5: e43, 2007

40. Chatterji M, Tsai CL and Schatz DG: Mobilization of RAGgenerated signal ends by transposition and insertion in vivo. Mol Cell Biol 26: 1558-1568, 2006. 